\title{
Communicating politics: using active learning to demonstrate the value of the discipline
}

\begin{abstract}
In the context of higher tuition fees, the Government's employability agenda and growing concern for defined career development strategies among young people, there is a need more effectively for Politics programmes to foster the capacity to communicate politics. Without communicating the implications and relevance of politics the subject and the skills derived from studying within Politics the discipline, Politics departments may face recruitment difficulties that those in, for example, the natural sciences, vocational subjects or the ascendant Business Management, may not. This article examines pedagogical means of promoting the capacity to communicate politics as part of an overall programme which integrates outreach, widening participation, recruitment, undergraduate study and employability activities. I focus, in particular, on applying salient approaches prominent within the Politics pedagogical literature to the development of the curriculum of a third year undergraduate module in the Department of Politics, Philosophy and Religion at Lancaster University: PPR389: Communicating Politics. I suggest that incorporating active learning and innovative teaching and assessment methods provides opportunities for meeting both student recruitment and employability agendas in Politics and beyond.
\end{abstract}

Keywords: Politics; skills; active learning; recruitment; employability

\section{Introduction}

Politics is an extremely broad discipline, concerning issues as large in scale as international conflicts and as small in scale as particular familial relationships. It is deeply misunderstood, often regarded, in the UK, merely as the study of white men in suits childishly point-scoring in Parliament. This narrow understanding of the nature, scope and implications of politics serves to a) dissuade young people from studying Politics at university, b) lead employers to under-appreciate the talents and transferrable skills of Politics students and c) undermine political capabilities and agency in the general public, particularly among those in disadvantaged communities who might benefit most from engagement with political ideas and activities (see discussion in Owen, 2000). Nyström, Abrandt Dahlgren and Owe Dahlgren (2008, p. 226) highlight the fact that the lack of an explicit or obvious career path means that Politics students often face difficulties that others in other fields do not: they 'leave their studies with an unclear picture of their professional trajectory; they have knowledge but they are searching for a professional field'. As Andres and Beecher (1989, p. 636) noted a quarter of a century ago,

We can all point to examples of a political scientist turned market researcher, a political scientist turned government employee, or a political scientist turned shoe salesman, and so on. Yet rarely does a political scientist seem to get hired in the public or private sectors because he or she is a political scientist.

Twenty five years on, the need to demonstrate the relevance and importance of a Politics degree is more pressing than ever.

At a time in which there is a 'growing "instrumentalisation" and "commodification" of the university sector', 'HE institutions are assessed and evaluated on their ability to deliver a good product both in terms of research, teaching and customer satisfaction' (Sloam, 2008, p. 511). With increases in tuition fees and an ever growing awareness of the importance of employability among prospective students (fostered, in part, by the UK Government's 
commitment to employability agendas - see Hale, 2008, p. 183; Yorke, 2004, etc.), there is a genuine need to ensure that the value of political study is clarified and emphasised. Indeed, among the state schools with which we have engaged as part of our departmental outreach (sharing our intellectual and disciplinary resources with individuals and institutions outside the university), widening participation (fostering opportunities for students from nontraditional academic backgrounds to enter higher education) and recruitment (attracting students) schemes, there is a gradual downward trend in A Level study in the humanities and social sciences, with students increasingly focused on adopting, at an early age, a study trajectory directed at achieving employment in lucrative and/or secure professions.

In one clear sense, there is scope for Politics departments to influence this trend beyond outreach by ensuring that students graduate able concisely to convey to potential employers and the general public the full value of their education and the transferrable skills they have developed through their study (see Baglione, 2008). As Clark (2011, pp. 135-136) has noted, 'Delivering transferable skills is particularly important when the degree with which the student will graduate is non-vocational', while Breuning, Parker and Ishiyama (2001, p. 657) have argued strongly that, 'Only if our majors understand what they have learned and what skills they have to offer can they have the "last laugh" as they climb the successive rungs of the career ladder'. This need is now enshrined in the Subject Benchmark Statement by the Quality Assurance Agency (2015), in which an emphasis on the importance to employers of the general capacity to communicate ideas is coupled with the subject specific capacity to analyse and understand practices, institutions and organizations. In order to deal as departments with both entry (i.e. recruitment) and exit (i.e. employability) issues, we need to ensure that students can communicate politics, its core concepts and methods to those with only lay experience of politics. Enabling graduates to demonstrate the relevance of their degrees to a range of careers, such as those associated with NGOs, governmental and local governmental bodies and private sector research organisations, not only improves their employability, it also improves the perceived viability of political study to prospective students.

This is true of Politics, but also of other non-vocational degrees, and the challenges faced and responses suggested can be applied beyond political study. It is important to state, at the outset, that while broadly similar skill sets may be advanced within the Social Sciences or Humanities, there is the clear distinction in content which creates different opportunities and challenges for those tasked with dealing with recruitment and employability agendas in their particular discipline. Students do not study skill sets - they study subjects and accumulate skills during the course of their study. They are attracted to subjects for distinct reasons and it is necessary when addressing the agendas above to articulate the relationship between the attractive and often underappreciated features of specific subjects and the skills accumulated by virtue of study. This article articulates one means using distinctively political material to demonstrate value and relevance in Politics. Approaches in Sociology or Geography might adopt elements of the structure of the programme, but, ultimately, the nature of the engagement will necessarily be different. In what ways can other social science disciplines deploy, for example, role plays or simulations, which are popular in Politics/IR precisely because they are concerned with political processes as well as content? It may be that other disciplines need different active learning techniques and resources that are beyond the disciplinary scope of this article. The article serves as stimulus for discussions along those lines in different subject areas.

In this article, I explore means of dealing with pressures through a Politics programme which integrates outreach, widening participation, recruitment, teaching and employability endeavours, centring, in particular, on a new third year undergraduate module entitled PPR389: Communicating Politics. I examine obstacles to communicating politics and 
pedagogical means of improving the communication of politics before advancing an overview of the approach adopted by the Department of Politics, Philosophy and Religion (PPR) at Lancaster University. I begin by highlighting one of the core problems with the communication of politics - the ill-defined and amorphous nature of politics itself.

\section{What is politics and why is it difficult to communicate?}

There are many divergent understandings of politics. The fact that Breuning, Parker and Ishiyama (2001, pp. 657-658) recommend that students gain comprehension of core concepts and methods suggests that Politics departments often struggle in ways that other, less eclectic disciplines or subject areas do not. As a starting point, and to grant this article some basic working context, it is useful to note Leftwich's (2004, p. 2) two accounts of politics:

The first - the arena, or site, approach - holds that politics is an activity found only in certain kinds of societies (normally, those with states) and in certain kinds of institutional sites or processes within those societies. The second approach is the processual approach, which holds that politics is a much more generalized and universal process which has existed wherever the human species has been found (though it certainly takes many different forms), and hence is a characteristic and necessary feature, if not a function, of all societies, past and present: it always has been and always will be, and therefore stateless societies have politics, too.

The institutional notion that politics exists only within particular institutions in societies with states is one which appeals on account of simplicity and etymology, referring back to the infrastructure of the Ancient polis. It is associated most clearly with approaches, such as forms of realism in International Relations, which are "most attached to the label "science" and most likely to acknowledge no qualitative difference between the subject matters of the natural and social sciences' (Hay, 2002, p. 66). However, particularly in its most narrow forms, this understanding both neglects the various institutional activities in all manner of societies which appear intuitively to be political and deprives us of the broader implications of politics of relevance to the real world.

The processual notion of politics as power can be found in Lasswell's (1936) classic 'Politics: Who Gets What, When, How'. Politics is the exercise of power and power is exercised in any number of different ways, in any number of different contexts and understood in any number of different ways by any number of different paradigms: for rational choice theorists, politics is the rational pursuit of interests (Weale, 2004); for Marxists, it is the expression of class conflict (Callinicos, 2004 and Hay, 2006), and for feminists, it is ubiquitous, marking the social relations at the heart of all societies (Squires, 2004). As Savigny and Marsden (2011, p. 4) point out, the lines between the institutional and processural accounts are blurred. In feminist accounts, for example, the personal is political insofar as the personal is oriented around institutions, such as the family, which liberal, statecentric accounts regard as belonging firmly in the private, non-political sphere. The underlying point, though, is that both institutional and processual conceptions are concerned with power and its exercise, with the latter conception merely appreciating more fully the range of situations in which that takes place.

Although messy, the broader, more general understanding of politics as the exercise of power, which includes the very negotiation and contestation of power, since such actions are exercises in and of power, provides, anthropologically, a much more substantive and compelling account. It enables us to recognise the political nature of businesses and their organisation, relations between teachers and pupils and contemporary issues as important as charity and aid. Perhaps most importantly, by adopting a broader understanding of politics, 
we come to challenge the overriding concern of potential students who are dissuaded of the merits of political study on account of its narrow orientation around British Politics and politicians in particular. How, though, might we enable students to communicate politics effectively, particularly to those beyond the discipline?

\section{Active learning and communicating politics}

Perhaps the overarching pedagogical deficit in political study is the failure fully to consider the importance of active learning (see discussion in Archer and Miller, 2011). For Bloom (1984), active learning, in which emphasis is placed on student participation and responsibility, aims fully to achieve six qualitatively distinct levels of understanding: knowledge, comprehension, application, analysis, synthesis, and evaluation. The benefits of more holistic pedagogical approaches are demonstrated in social science teaching in the finding that 'students retain $10 \%$ of what they read, $20 \%$ of what they hear, $30 \%$ of what they see, $50 \%$ of what they see and hear, $70 \%$ of what they say, and $90 \%$ of what they do and say together' (Boyer, Caprioli, Denemark, Hanson, and Lamy, 2000, p. 4). Where active learning has been neglected, Politics teaching has failed fully to maximise its impact and demonstrate its relevance to students and the general public beyond. The neglect of active learning is evident in, often understandably, conservative teaching and assessment methods (see discussion in Sloam, 2008, p. 513).

With regard to teaching, the lecture-centric format, although an efficient means of conveying large chunks of information quickly (Omelicheva and Avdeyeva, 2008), is a relic of a prior, scholastic age, in which scholars would read from texts to often illiterate students, acting merely as a mediator between text and ear (MacDonald Ross, 2011, p. 2). With regard to assessment, focus is often directed towards preparing students for essay-based assessments which, according to Buehler and Schneider (2009), merely assess the first three levels of understanding: the capacity of students to recall information, demonstrate comprehension and apply it to a given context. This fails to enable students to graduate with the requisite knowledge and individual capacities confidently to communicate politics in a coherent and substantive manner. It fails to do justice to the discipline and undermines its viability, not just in terms of student intellectual development, but also in terms of instrumental careerism, since students are less able to demonstrate the relevance of their study.

Efforts innovatively to deal with this pedagogical deficit in Politics have a long history. 15 years ago, Penny Welch (2000, p. 103) highlighted a range of emerging approaches of relevance to the discipline which might foster a more active pedagogical focus. They include i) much greater concern for transferrable skills (Welch, 1996), ii) the use of more interactive lectures and more structured seminars (Jenkins, 1995 and Wood and Moran, 1994), iii) the now standard use of electronic teaching resources (Crowther and Barnett, 1997) and other audio-visual aids (see Peters and Beeson, 2010; Roberts, 2008), iv) the use of internships and placements (Annette, 1999), and v) the deployment of new assessment formats assessing spoken as well as written work (Stafford, 1997). Two decades on from some of these suggestions, innovations have, in many departments, been explored and adopted only partially. While the importance of i) is the motivation for this article, there is a need for much greater adaptation, adoption and development of the remaining approaches. Several means of advancing these innovations efficiently and effectively present themselves with regard to teaching methods, skills and civil engagement.

\section{Teaching methods}

In the first instance, Huerta (2007) has challenged the notion that active learning has a place specifically within small, seminar-style formats. Rejecting the secure option of focusing on organisation and structure, Huerta (2007, p. 238) argues that lessons learned from other 
disciplines suggest that 'asking for student comments, having the students break into small discussion groups, role-playing, and having students write down reflections about the class discussion' are basic, easy and varied means of incorporating active learning techniques into lectures which do not detract from the coherence and cogency of the lecture itself. In Huerta's (2007) case, the results of adopting more active styles were that grades either remained the same or increased and that student experience improved. However, modest, rather than radical, innovations had a greater impact, since the students still had access to the knowledge, comprehension and application granted by the lecture, suggesting that combining elements of seminar and lecture formats in the same forum can offer significant benefits.

Perhaps the most common, interactive means of introducing active learning into Politics and, in particular, IR (see, for example, Dougherty, 2003 and Frombgen et al., 2013), teaching has been through role play scenarios and simulations (see Shellman, 2001 and Newman and Twigg, 2000). Role play scenarios and simulations are means of recreating elements of real world political situations in controlled pedagogical environments. They are intended to enable students imaginatively to adopt, develop and practise the interests, motivations, intentions, powers and traits of particular political actors within particular contexts. As Smith and Boyer note, while some have regarded their use as amounting to little more than 'playing games' or have disregarded their potential on account of the difficulty of their development, where they are deployed, they are effective means of 1) giving 'students a deeper level of insight into the political process', 2) encouraging 'students to be more attentive and more active in the learning process', 3) helping 'students retain information for longer periods of time', 4) developing 'critical thinking and analytical skills through collaborative efforts', and 5) enabling 'students to develop speaking and presentation skills, simultaneously building their confidence' (Smith and Boyer, 1996, pp. 690-691; see also Brown and King, 2000).

In designing scenarios, it is essential: that prior thought is given to whether the focus lies on comprehension of processes or content (Asal and Blake, 2006, p. 2); that there is concern for the different preparation, interaction and debriefing stages of the scenario (Asal and Blake, 2006, p. 3); that the scenario is interesting and relevant (Hess, 1999, p. 1); that it is cost and time efficient (Asal, 2005, p. 371); that the instructions are clear, the goals evident and the context tangible; that the role statements on the actors are sufficiently detailed as to enable character formation, but sufficiently concise as to avoid irrelevance; that the timeframe within which to prepare for the scenario is broad, so as to ensure effective engagement, and that written debriefings are constructed so as to ensure substantive reflection (Petranek, 2000). Effective scenarios ensure that students not only retain more information, they also develop transferrable, responsive analytical skills of great importance to a number of professions.

\section{Skills}

One of the most significant implications of the general concern for interaction seen in Huerta's lectures and in role play scenarios is that more care should be taken to foster and assess oral communication skills. The likes of Buehler and Schneider have highlighted the use of oral examinations in foreign language degrees as useful means of students 'demonstrating their verbal and critical assessment skills in possible impromptu situations' (Buehler and Schneider, 2009, p. 315). Oral exams which test students' abilities to respond to unpredictable stimuli provide scope for additional levels of 'analysis, synthesis, and evaluation of the required material' (Buehler and Scheider, 2009, p. 316). As Stafford has argued, oral examinations do not represent a lowering of standards, as those who privilege essay writing might suggest. Rather, the skills they develop are 'indubitably both relevant and valuable. To many employers they are as important as reading and writing skills. But they are 
not simply enterprise skills', they are also means of promoting democratic participation (Stafford, 1997, p. 198).

Stafford favours a Habermasian focus (see Habermas, 1970, p. 367), promoting the democratic ideal by fostering communicative competence in students (see also Sloam, 2008, pp. 516-517). That 'is to say, the necessary communication skills to put across their point of view; they are effective at challenging factual, theoretical and normative claims and practical proposals; and the interchange itself is undominated' (Stafford, 1997, p. 198). There are many different elements and forms of communication to consider when seeking to achieve these ends. These include 1) making a presentation, 2), defending a presentation, acting as a discussant, 4) engaging in an unstructured discussion, 5) chairing, 6) asking questions, and 7) answering questions. Each of these roles stimulates different skills or traits. Although Stafford enumerates these extensively, they can be reduced to general themes of concision, timing, clarity, cogency and coherence in presentation, critical thinking, open-mindedness, incisiveness, rigour and fairness in intellectual approach, and courtesy and respect in interpersonal conduct (Stafford, 1997, p. 199). These qualities can only be developed by students experiencing, understanding and reflecting upon each of these roles. In Stafford's case, this is fostered through a range of different seminar formats which grant students different levels and forms of power and authority, with grades awarded on account of the extent to which student participation realizes the qualities above. It is noted that assessment of oral skills, in line with Huerta's introduction of active learning methods, constitute at most a modest element of overall assessment in modules (Stafford, 1997, p. 202).

The skills promoted by Stafford are of great importance to a range of different professional roles. One means of advancing additional areas of professional development is through the introduction of video production skills (see Whiteman, 2003, p. 89) into modules which focus on oral assessments. By recording presentations, students accumulate experience of presenting to camera and the capacity to produce short films. A number of universities now use short student, as well as academic, videos as part of their recruitment campaigns (see, for example, University of Notre Dame, 2014). Recording presentations as part of assessments also provides an opportunity to collect material to use in outreach, widening participation and recruitment programmes.

Beyond oral presentation, Trueb (2013) is surely correct to argue that students graduate inexperienced in the art of writing for lay or non-academic audiences. For Trueb, these skills are best advanced through a strategy paper simulation which combines policy writing and foreign policy decision making, enabling students to inform audiences of important contextual information and advancing cogent arguments capable of appealing to non-academic actors. This approach is also endorsed by Sherman and Waismel-Manor (2003), who argue that relative deficits in writing styles among Politics students can only partially be addressed by writing classes. Simulations 'make the strategic writing choices of various actors and interests explicit, helping the students gain a deep and critical understanding of politics from the perspective of actors and the audiences for which they write' (Sherman and Waismel-Manor, 2003). Writing for an audience which is not the tutor or lecturer is an experience of much greater relevance to students' future professional lives.

The most common means of improving writing skills during study is or at least should be through engagement in the feedback process (see Sloam, 2008, p. 519). Throughout the course of their study, students (should) receive regular and substantive feedback. While receiving feedback is an important formative experience (though it 'may come too late to affect student learning' (Cohen, 2008, p. 609)), without practising the analytical and communicative skills needed to provide feedback, students miss out on both active learning and the development of transferable skills. There is a need more seriously for students to be engaged in providing feedback while they study, both as a means of applying their 
knowledge to the work of others and also as a means of reflexive analysis and selfdevelopment, enabling them to examine their own work according to external criteria. This is an essential skill required in most professional settings.

Damron (2003) has sought to develop this capacity for reflexivity through poster presentations, in which students present to and receive feedback from their peers. Baranowski and Weir (2011) have shown that peer evaluation is of great importance in ensuring engagement in and benefits from presentations. Baglione (2008), on the other hand, has sought to foster 'superlative' writing skills by 'demystifying' the academic paper writing process which, she argues, is too often ignored in Politics teaching. She does this by breaking up the structure of academic papers into manageable and distinct chunks, arguing that 'identifying and understanding the debate within a field, designing a strategy for evaluating competing claims, finding appropriate information, engaging in an analysis of that data, and communicating this process and its results to others' are essential skills which should be developed during study in order to 'enhance [students'] capacity as citizen-decision makers' (Baglione, 2008, p. 596). One of the big problems that students face is that, unlike academic writers, they do not usually have the opportunity to revise their work in accordance with feedback for final submission and publication. Providing that opportunity and encouraging students to take advantage of it presents the possibility of a shift in thinking away from summative and towards formative concern. Moreover, enabling students to provide feedback, such as through a peer-review process, presents students with an opportunity to reconsider their perceptions of markers' often enigmatic interests and motivations, since they are able to approach the provision of feedback with their own interests and motivations in mind, potentially improving their receptiveness to feedback (see Baglione, 2008, p. 598).

\section{Civil engagement: placements and internships}

Perhaps the most substantive practical means of instilling and consolidating personal and intellectual capacities for communicating Politics lies in the use of placements and internships. The literature on internships and placements has a long history, with Hirschfield and Adler (1973) evaluating programmes which emerged in the wake of WWII and Gryski, Johnson and O'Toole (1987) arguing that the literature on such approaches has been patchy and that the programmes which have emerged have done so organically, representing the institutional structure and goals of departments rather than some fixed pedagogical commitments. The most significant theoretical work behind the use of placements lies in Boyer's (1990 and 1996) notion of the 'scholarship of engagement'. This account places academia in a civic context, arguing that scholarship fulfils four key social roles: the scholarship of discovery through research; the scholarship of integration through situating ideas within broader contexts; the scholarship of sharing knowledge through dissemination beyond academia and the application of knowledge, in which theory and practice interact reflexively informing one another in the process.

Inspired by The Enlightenment, proponents of academia as benevolent public or civic service believe that, by consciously performing these roles, the scholarship of engagement contributes to the ideas and practices of society as a whole, driving forward human wellbeing (Katula and Threnhauser, 1999, pp. 249-250). Campbell (2000) goes as far as to suggest that the practice of placements promotes social capital in students, which Robert Putnam (1995, p. 67) holds to refer to 'features of social organization such as networks, norms, and social trust that facilitate coordination and co-operation for mutual benefit'. The more students are situated in rich community networks, the better they are able to engage in 'service-learning' (see Battistoni, 2000), see their activities in terms of social capital and value reciprocity (Campbell, 2000; see also Barker, 2004, pp. 126-127). In this spirit, which resonates with Stafford's concern for discursive development, Colby, Beaumont, Ehrlich and 
Corngol (2007) have presented such professional opportunities as important means of preparing people for democratic participation - a suggestion that receives partial empirical support by Hunter and Brisbin (2000) (see also Owen, 2000) -, particularly where students are encouraged to view service and politics normatively in terms of the same moral continuum (see Walker, 2000). One problem, however, is that people have often referred to these activities as forms of 'Civic engagement', which, 'as it is currently used includes political, social, and moral components, or the entire "kitchen sink" of public and private goods' (Berger, 2009, p. 335). For Berger (2009), much greater clarity is needed, with concern for any form of 'civic activity, whether it be participation in bowling leagues or volunteering in soup kitchens, replaced with concern for 'civil' engagement, which has a specifically moral and social focus in line with traditional notions of service. The importance of students engaging in the latter activities is demonstrated by 'the available research', which 'suggests a positive correlation between social capital - which encompasses what I have called social and also moral engagement - and economic and governmental efficiency, highperforming schools, life satisfaction, and even life expectancy (Berger, 2009, p. 344).

For Sherrington et al. (2008), the absence of service thinking or 'civil' engagement in UK HE institutions has created a series of pedagogical deficits and failed to fulfil the demand among external stakeholders for participation and involvement. Although placements are an increasing feature of Politics degree experiences, they are often poorly organised, too long, excessively concerned with work experience, insufficiently concerned with research and disconnected from the content of degrees (Curtis et al., 2009). Creating 'a repertoire of examples of the Scholarship of Engagement for Politics', Sherrington et al. (2008, pp. 174175) seek to facilitate co-operation between 'students, placement providers, and academics to move away from the notion of placements as purely "work" experience by establishing research-led placements, whereby students undertake a specified research task with the placement provider'. Students apply abstract theories to the conditions they encounter during their placements, experiencing 'politics in action', developing deep knowledge of the subject, communicating their knowledge effectively and increasing employability as a consequence (see Curtis et al., 2009). Emphasising the research-led nature of placements, they (2008, p. 178) argue that, where placements do exist, too often they focus exclusively on general skills, rather than the discipline itself, failing fully to maximise the potential benefits of the experience. They (2008, p. 179) assert several key guidelines on the integration of placements into the curriculum:

Embedding placement learning in the politics curriculum is not an easy task, and the practicalities can seem quite daunting for academics and students alike. To this extent, we have advocated that placements should be of short duration (between one and eight weeks), should run during the academic year alongside a student's programme of study, and should be regional wherever possible (to defray financial costs). The placement should be linked to a specific module, and should be structured by the learning outcomes of that module. The placement should also be formally assessed.

They also suggest that students benefit most from the experience of placements in the second year, as this allows time for reflection. The placements they developed in their trial were all with organisations with an explicitly 'political' focus in the institutional understanding of the term. The one failure they experienced was due to the research exercise being set with insufficient clarity by the placement provider. Interestingly, in several cases, they found that students themselves only discovered the relevance of their degrees during or as a result of their placements. As one noted, 'Who'd have thought something that you learn in a class room would actually be relevant in real life!' (Sherrington et al., 2008, p. 183). However, this 
must be tempered by the finding of Moon and Schokman (2000, pp. 173-175) that, where policy process internships are associated with modules, students sometimes struggle to see the relationship between theory and practice. Even then, though, students benefited from having a political research focus more than they would have done had they simply engaged in a vocational experience.

The literature suggests therefore a series of approaches of value to promoting the capacity to communicate politics. Most broadly, there is a need for deep and active learning, with innovative teaching and assessment methods incorporated into modules. These innovations include: diversification in lecture format; the introduction of creative, practical activities, such as role play scenarios; the teaching and assessment of oral communicative skills, particularly where this can be combined with additional professional experience; the use of more interactive forms of writing development, including through reflexive forms of feedback, and the development of research-led placements imbued with the 'scholarship of engagement'.

How, though, can we apply these innovations in a module aimed at improving communicative skills?

\section{Situating teaching within the context of outreach, widening participation and recruitment}

As a Politics/IR subject area at Lancaster University, we are attempting to develop an intensive, innovative programme which integrates our entry (outreach, widening participation and recruitment), teaching and exit (employability) activities into a cohesive programme. In terms of entry, among other initiatives, we are advancing a programme of engagement with schools and sixth form colleges in the North of England as part of a pilot study throughout 2014-2015. By creating 'feeder' schools, with close institutional and personal ties to the Department, we are working directly with teachers and students to identify and overcome obstacles to prospective students studying Politics at Lancaster. As part of this, we engage directly with schools through i) subject and university presentations, ii) discussions with parents at careers and enrichment fairs, iii) workshops for AQA Extended Project Qualification (EPQ) students completing projects in Politics and related topics (activities i), ii) and iii) all held at host schools), iv) two day role play scenario and Question Time events (held at regional hubs - schools which can accommodate students from neighbouring schools as well as their own), v) regionally co-ordinated visits of potential students from several different schools to Lancaster and vi) an annual headline event which will bring 50 of the keenest young (16-18 year old) political minds to Lancaster for a two day workshop, during which they will work directly and intensively with the Department of Politics, Philosophy and Religion's Richardson Institute (RI) to create and present a report on key contemporary issues. This work complements our Departmental outreach work (PPR 2014), which focuses on taking our disciplines and research into schools to share intellectual resources and stimulate critical thinking among young people about issues of relevance to our subjects.

During their degrees in our department, students have the opportunity to undertake research-led internships through the RI, which is the UK's longest established Peace and Conflict research centre, specializing in interdisciplinary and trans-disciplinary study of contemporary conflict, with a specific focus on empirically driven applied research. Led by Dr Simon Mabon, the RI engages directly with a range of external bodies, such as NGOs, Civil Service Departments and think tanks, to facilitate year-long internships for undergraduate and postgraduate students. Students are provided with preliminary research training prior to and during the internship. The research they conduct is not assessed as part of a module, but fosters the very skills identified in the literature on internships and 
placements, increasing their employability, not least as a result of the publication (article, report, briefing, etc.) they produce as part of their work.

In terms of assessed modules, we have PPR394: Dissertation with External Collaboration, which provides students with similar opportunities for placements and internships, but with the written work assessed. More centrally focused on education is PPR390: PPR in Education, which provides students with opportunities to experience teaching in schools, focusing specifically on teaching assistance, small group work and reflexive evaluation of the coherence between different forms of teaching. Steps are underway to increase assessed modules with external partnerships at both BA and MA level, with a greater focus on employability advanced through short placements. It is into this framework that PPR389: Communicating Politics will be introduced in 2015-2016, with the aim of tying together entry and exit concerns through the assessment methods.

\section{Teaching structure and content}

The ten week module which emerges from the review of the Politics pedagogical literature is taught through integrated lecture-workshop sessions, with sixty minute interactive lectures followed by ninety minute workshops, both of which will involve group discussions, presentations and practical demonstrations of innovative teaching methods.

The structure of the module consists of four related parts (see Table 1). In the first part, the module seeks to identify and consolidate awareness of the basic definitions of core concepts required to explain politics to lay audiences. It then seeks to place those concepts within the much broader disciplinary framework that experts in the subject require in order to develop programmes of communication and knowledge exchange with those audiences. In the second part, the module seeks to analyse and identify the key qualities required to communicate political ideas orally and visually. Tracing some of the core trends in the history of political communication and oration, the sessions in this section seek to equip students with the skills required to present short, effective talks, in particular, on politics and the students' areas of interest. This leads into the first, presentational, assessment in week five. In the third part, the module seeks to examine the fundamental components of effective writing. Beginning, with general discussion of content, structure and style, the section then seeks to apply those principles to three formats of relevance to Politics students and graduates - essays, dissertations and reports -, before asking students reflexively to build on their experiences of receiving feedback to develop means of providing constructive criticism to others. This leads into the second, feedback, assessment in week eight. The final section considers alternative means of demonstrating and explaining political theory, institutions and behaviours through simulations and role plays. Drawing on the increasingly rich literature on the use of simulations in IR, in particular, students are introduced to the rationale of the approach and the importance of contexts and characters in developing successful events. Students develop their own role plays as their third, simulation, assessment and have an opportunity to test and revise their work in the final week of teaching.

In terms of learning outcomes, the aim is to ensure that, on successful completion of the module, students are able effectively to communicate politics to different audiences by virtue of: (a) consolidating knowledge of clear, concise definitions of core political concepts, (b) placing political concepts, approaches and research methods within a comprehensible framework, (c) identifying and understanding key features in effective oral and visual presentation of political ideas, (d) presenting/articulating political concepts and ideas effectively, (e) understanding the core qualities required to write effective Politics essays, dissertations and reports, (f) providing constructive criticism of work in politics, (g) understanding alternative pedagogical methods and the place of simulations and role-plays in Politics, (h) developing knowledge of the background and context of their topic of choice for 
their simulation assessment, (i) examining the motivations of actors in their simulation, (j) appreciate the importance of audience background, interests and qualities in explaining politics to lay audiences, $(\mathrm{k})$ appreciating the importance of innovation, engagement and enthusiasm in communicating with specific audiences, (l) helping sixth form students develop an interest in Politics and the skills required to enter higher education.

While the teaching focus of the module retains a core concern for incorporating active learning elements into the solid framework of lectures, in accordance with Huerta's recommendation, the assessment methods are much more radical, offering new opportunities to integrate recruitment, teaching and employability.

\section{Assessment strategies: integrating entry and exit requirements}

In order to combine entry and exit concerns, the module seeks to integrate assessment outputs with recruitment activities in an expansive programme of engagement with schools and sixth form colleges.

In the first assessment, which accounts for $20 \%$ of the total mark, students prepare and present a six minute talk to camera. This will be recorded on video in Lancaster University's TV studio and edited by the students individually using university facilities and resources. The format is similar to Lancaster University's PPR Departmental staff 'How I became Interested...' promotional videos (see Lancaster University 2013). Students have six minutes in which to: a) define politics and discuss its scope, b) identify and describe a political issue that they regard as being important and/or interesting and, c) explain how that issue can be approached, researched and analysed. Students complete their presentation assessment individually in allocated slots during an assessment session, which are held in addition to the lecture-workshop sessions, in week five. Students receive feedback within one week of submission.

In the second assessment, which accounts for $40 \%$ of the total mark, students complete two 500 word written feedback sheets on project plans for, and a writing sample from, two AQA Extended Project Qualification (EPQ) Level 3 projects (one feedback sheet per project) by students from our feeder schools in the North East of England. EPQ Students who meet widening participation criteria are given priority in receiving feedback. The projects are broadly be within the field of Politics. Our students do not need prior, detailed knowledge of the specific topic of the projects. They are expected to acquaint themselves with the topic and provide some comments on content and, potentially, research on that content, but their main focus lies in providing feedback on the feasibility, research methods and structure of the plan and the clarity, cohesiveness and style of the writing sample. The feedback is double-blind, with both the projects and the feedback completed anonymously. There is no direct contact between sixth form EPQ student and PPR Politics student. The module convener marks and moderates the feedback before it is returned to the EPQ students so as to ensure a consistently high level of support. Our students receive feedback on their assignments in light of the moderation within one week of submission.

In the third assessment, which accounts for $40 \%$ of the total mark, students develop a 2,500 word written role play scenario of a real-world political crisis. The role play a) outlines the relevant background and context to the crisis, b) sets out the institutional and procedural structure within which actors work and through which the crisis is negotiated, c) describes the actors within the structure, outlining their characters, interests, agendas, powers and capacities, d) outlines the ends to which the participants in their specific roles must work, and e) lists any injunctions to be deployed to ensure that the scenario remains fluid, dynamic and interesting. In effect, the students produce a basic tool-kit for a scenario and have an opportunity in week ten to work with their peers to test and improve their scenarios. 
The material produced by the students as part of their assessments is considered for use in departmental outreach and recruitment campaigns. Permission is sought from students for selected videos produced as part of the presentation assessment to be used both in online publicity and recruitment campaigns as well as during subject and university presentations to schools. The feedback provided on EPQ student projects fosters our feeder system with schools, bringing school and sixth form students closer to the university experience of feedback, enabling our students to transfer the knowledge accumulated from their experiences to prospective students and helping, in particular, students who meet widening participation criteria to receive the sort of assistance required to gain qualifications necessary to enter university. Finally, selected role play scenarios are used during two-day workshops conducted at regional hubs, during which groups of up to 100 sixth form students from a range of different schools and colleges work together to engage with an issue of pressing importance on the first day, before returning for a Question Time event on the second day, at which they apply the knowledge and communicative skills gleaned from the first day in engaging with invited speakers on the topic of the scenario. Selected students from the module are offered the opportunity to assist in running their role play scenarios at these events, thereby gaining invaluable experience of demonstrating political processes. However, participation is not obligatory, occurs after the end of the module and does not affect their overall assessed mark for the module.

\section{Conclusion}

The approach above is, of course, one possible response among many to pressing and often seemingly overwhelming demands from a range of external and internal sources. The circumstances within which Politics departments, in the UK, in particular, though not exclusively, operate seem beyond control, with increasing instrumentalism fostered by broader economistic approaches to learning. However, there are ways in which the viability of the subject and discipline can be promoted. More active approaches to pedagogy and greater integration of entry, learning and exit strategies are sensible and, in some cases, unavoidable in the current climate. Communicating politics is central to this for those in the discipline. In some respects, dealing with the pressure that departments face by promoting the capacity of students to communicate politics can lead to serious improvements in student learning and experience. Active learning, pedagogical innovation, external engagement and the integration of entry, teaching and exit endeavours can be valuable on a number of levels.

Fundamentally, we should take seriously the notion that the teaching we do should enable people to find jobs and achieve ends that they find meaningful. Rejecting that on the grounds of commitment to the intrinsic value of Politics or Liberal Arts teaching has sometimes appeared to be an excuse for aversion to recalibration and revision of programmes. Concern for employability and providing private sector companies with skilled employees whose education they appear reluctant to support through taxes understandably seems galling to many. However, there is something of great importance in the idea of civil engagement and, in providing students with the skills to communicate politics, Politics departments have the capacity to foster in people the ability to engage more effectively with political arrangements, institutions and activities. Within recruitment drives lies the possibility of socially responsible transmission of capacities, through outreach and widening participation, to vulnerable groups whose political capacities might otherwise be left untapped, since it seems that very few attempts are made by others to engage substantively in this respect. We should not forget that, in demonstrating viability and helping people to communicate politics, we not only help people to work within systems with which we may disagree, we also provide people, in however slight a form, with capacities to challenge elements of those systems. 
While this article has focused on potential responses by Politics departments to the challenges posed by the current climate in higher education, the general suggestions are of broader relevance to other departments and disciplines offering non-vocational degrees: the need to focus on skills, incorporate active learning and develop innovative pedagogical methods is pressing; the integration of entry, learning and exit programmes is valuable, not least in order to ensure efficiency and depth in each of those endeavours, and the shift towards civil engagement as a means of underpinning departmental activity is socially important at a time of great instrumentality. Realized in discipline appropriate forms, these general principles may be useful means of promoting degrees of study with less clear professional pathways. While it is beyond the scope of this article to suggest means by which other disciplines can advance their agendas, I hope that the example of Politics/IR at Lancaster provides colleagues with stimuli to develop approaches which meld the general with the particular in ways that promote the interests of current and prospective students best.

\section{References}

ANDRES, G. J. and BEECHER, J. A. (1989) Applied political science: Bridging the gap or a bridge too far?, PS: Political Science \& Politics, 22, 636-639.

ANNETTE, J. (1999) Education for citizenship, service learning and political science, Paper given at PSA Conference, April.

ARCHER, C. C. and MILLER, M. K. (2011) Prioritizing active learning: An exploration of gateway courses in political science, PS: Political Science \& Politics, 44, 429-434.

ASAL, V. (2005) Playing games with international relations, International Studies Perspectives, 6, 359-373.

ASAL, V. and BLAKE, E. L. (2006) Creating simulations for political science education, Journal of Political Science Education, 2, 1-18.

BAGLIONE, L. (2008) Doing good and doing well: Teaching research-paper writing by unpacking the paper, PS: Political Science \& Politics, 41, 595-602.

BARANOWSKI, M. and WEIR, K. (2011) Peer evaluation in the political science classroom, PS: Political Science \& Politics, 44, 805-811.

BARKER, D. (2004) The scholarship of engagement: A taxonomy of five emerging practices, Journal of Higher Education Outreach and Engagement, 9, 123-

BATTISTONI, R. M. (2000) Service learning in political science: An introduction, PS: Political Science \& Politics, 33, 615-616.

BERGER, B. (2009) Political theory, political science and the end of civic engagement, Perspectives on Politics, 7, 335-350.

BLOOM, B. S. (1984) Taxonomy of educational objectives (Boston, MA: Allyn and Bacon).

BOYER, E. (1990) Scholarship reconsidered: Priorities of the professoriate (New York: The Carnegie Foundation for the Advancement of Teaching, University of Princeton).

BOYER, E. (1996) The scholarship of engagement, Journal of Public Outreach, 1, 11-20.

BOYER, M. A., CAPRIOLI, M., DENEMARK, R. A., HANSON, E. C. and LAMY, S. L. (2000) Visions of international studies in a new millennium, International Studies Perspectives, 1, 1-10.

BREUNING, M., PARKER, P. and ISHIYAMA, J. T. (2001) The last laugh: Skill building through a liberal arts political science curriculum, Political Science \& Politics, 34, 657-661.

BROWN, S. W. and KING, F. B. (2000) Constructivist pedagogy and how we learn: Educational psychology meets international studies, International Studies Perspectives, 1, 245-254.

CALLINICOS, A. (2004) Marxism and politics. In A. LEFTWICH (Ed), What is politics?: The activity and its Study (Cambridge: Polity), 53-66. 
CAMPBELL, D. E. (2000) Social capital and service learning, PS: Political Science \& Politics, 33, 641-646.

CLARK, A. (2011) Embedding transferable skills and enhancing student learning in a political science research methods module: Evidence from the United Kingdom, PS: Political Science \& Politics, 44, 135-139.

COLBY, A., BEAUMONT, E., EHRLICH, T. and CORNGOL, J. (2007) Educating for Democracy: Preparing Undergraduates for Responsible Political Engagement (San Francisco: Jossey Bass).

COHEN, M. (2008) Participation as assessment: Political science and classroom assessment techniques, PS: Political Science \& Politics, 41, 609-612.

CROWTHER, D. and BARNETT, N. (1997) Computer-based learning in political science: A multimedia approach, Contemporary Political Studies, 2, 905-917.

CURTIS, S., AXFORD, B., BLAIR, A., GIBSON, C., HUGGINS, R. and SHERRINGTON, P. (2009) Making short politics placements work, Politics, 29, 62-70.

DAMRON, D. (2003) Facilitating critical feedback on capstone papers through student poster sessions, PS: Political Science \& Politics, 4, 777-780.

DELLI CARPINI, M. X. and KEETER, S. (2000) What should be learned through service learning?, PS: Political Science \& Politics, 33, 635-638.

DOUGHERTY, B. K. (2003) Byzantine politics: Using simulations to make sense of the Middle East, PS: Political Science \& Politics, 239-244.

FROMBGEN, E., BABOLA, D., BEYE, A., BOYCE, S., FLINT, T., MANCINI, L. and VAN EATON, K. (2013) Giving up control in the classroom: Having students create and carry out simulations in IR courses, PS: Political Science \& Politics, 46, 395-399.

GRYSKI, G. S., JOHNSON, G. W. and O’TOOLE, L. J., Jr. (1987) Undergraduate internships: An empirical review, Public Administration Quarterly, 11, 150-170.

HABERMAS, J. (1970) Towards a theory of communicative competence, Inquiry, 13, 360375.

HALE, S. (2008) Innovations in learning and teaching politics, European Political Science, 7, 133-134.

HAY, C. (2002) Political analysis: A critical introduction (Basingstoke: Palgrave).

HAY, C. (2006) (What's Marxist about) Marxist state theory?, In C. HAY, M. LISTER and D. MARSH (Eds.), The state: Theories and issues (Basingstoke: Palgrave), 59-78.

HEPBURN, M. A., NIEMI, R. G. and CHAPMAN, C. (2000) Service learning in college political science: Queries and Commentary, PS: Political Science \& Politics, 33, 617622.

HESS, F. M. (1999) Bringing the social sciences alive (Needham Heights, MA: Allyn and Bacon).

HIRSCHFIELD, R. S. and ADLER, N. M. (1973) Internships in politics: The CUNY experience, PS: Political Science \& Politics, 6, 13-18.

HUERTA, J. C. (2007) Getting active in the large lecture, Journal of Political Science Education, 3, 237-249.

HUNTER, S. and BRISBIN, R. A. Jr. (2000) The impact of service learning on democratic and civic values, PS: Political Science \& Politics, 33, 623-626.

JENKINS, A. (1995) Lecturing is a political activity?, Politics, 15, 135-140.

KATULA, R. A. and THRENHAUSER, E. (1999) Experiential education in the undergraduate curriculum, Communication Education, 48, 238-255.

LANCASTER UNIVERSITY (2013) How I got interested in.... Politics, Philosophy and Religion Departmental Website [video]. Retrieved from http://www.lancaster.ac.uk/fass/ppr/undergraduate/politics/index.htm. 
LEFTWICH, A. (2004) Introduction. In A. LEFTWICH (Ed.), What is politics?: The activity and its study (Cambridge: Polity), 1-22.

MACDONALD ROSS, G. (2011) What's the use of lectures?: Forty years on, Discourse: Learning and Teaching in Philosophical and Religious Studies, 10, 1-7.

MENDEL-REYES, M. (1997) Teaching/theorizing/practicing democracy. In R. M. BATTISTONI and W. E. HUDSON (eds.), Experiencing citizenship: concepts and models for service-learning in political science (Washington, DC: American Association for Higher Education), 15-34.

MENDEL-REYES, M. (1998) A pedagogy for citizenship: service learning and democratic education, New Directions for Teaching and Learning, 73, 31-38.

MIT (2014) Videos, MIT Political Science Website [Videos]. Retrieved from http://web.mit.edu/polisci/videos/index.html.

MOON, J. and SCHOKMAN, W. (2000) Political science research internships and political science education, Politics, 20, 169-175.

NEWMANN, W. W. and TWIGG, J. L. (2000) Active engagement of the intro IR student: A simulation approach, PS: Political Science \& Politics, 33, 835-842.

NYSTROM, S., ABRANDT DAHLGREN, M. and OWE DAHLGREN, L. (2008) A winding road: Professional trajectories from higher education to working life: a case study of political science and psychology graduates, Studies in Continuing Education, 30, 215-229.

OMELICHEVA, M. Y. and AYDEYEVA, O. (2008) Teaching with lecture or debate? Testing the effectiveness of traditional versus active learning methods of instruction, PS: Political Science \& Politics, 41, 603-607.

OWEN, D. (2000) Service learning and political socialization, PS: Political Science \& Politics, 33, 639-640.

PETERS, R. and BEESON, M. (2010) Reducing the gap between skills sought by employers and developed by education, PS: Political Science \& Politics, 43, 773-777.

PETRANEK, C. F. (2000) Written debriefing: The next vital step in learning with simulations, Simulation and Gaming, 31, 108-119.

PPR (Politics, Philosophy and Religion) (2014) Links with schools, Lancaster University Website. Retrieved from http://www.lancaster.ac.uk/fass/ppr/outreach/.

Quality Assurance Agency (2015) Subject Benchmark Statement: Politics and International Relations, Quality Assurance Agency Website. Retrieved from http://www.qaa.ac.uk/en/Publications/Documents/SBS-politics-15.pdf

RICHARDSON INSTITUTE (2014) Richardson Institute internship programme, Lancaster University Website. Retrieved from http://www.lancaster.ac.uk/fass/centres/richinst/internship-programme.htm.

ROBERTS, M. (2008) Adventures in podcasting, PS: Political Science \& Politics, 41, 585593.

SAVIGNY, H. and Marsden, L. (2011) Doing Political Science and International Relations: Theories in Action (Basingstoke: Palgrave).

SHELLMAN, S. M. (2001) Active learning in comparative politics: A mock German election and coalition-formation simulation, PS: Political Science \& Politics, 34, 827-834.

SHERMAN, D. J. and WAISEL-MANOR, I. (2003) Get it in writing: Using politics to teach writing and writing to teach politics, PS: Political Science \& Politics, 36, 755-757.

SHERRINGTON, P., AXFORD, B., BLAIR, A., CURTIS, S., HUGGINS, R. and GIBSON, C. (2008) Research-led placements in politics: A new approach?, European Political Science, 7, 175-185.

SLOAM, J. (2008) Teaching democracy: The role of political science education, The British Journal of Politics \& International Relations, 10, 509-524. 
SMITH, E. T. and BOYER, M. A. (1996) Designing in-class simulations, PS: Political Science and Politics, 29:4, 690-694.

SQUIRES, J. (2004) Politics beyond boundaries: A feminist perspective. In A. LEFTWICH (Ed.), What is politics?: The activity and its study (Cambridge: Polity), 1-22.

STAFFORD, W. (1997) Teaching and assessing oral skills as democratic practice, Politics, 17, 197-203.

TRUEB, B. (2013) Teaching students to write for "real life": Policy paper writing in the classroom, PS: Political Science \& Politics, 46, 137-141.

UNIVERSITY OF NOTRE DAME (2014) Undergraduate programme, University of Notre Dame political science website. Retrieved from http://politicalscience.nd.edu/undergraduate-program.

WALKER, T. (2000) The service/politics split: Rethinking service to teach political engagement, PS: Political Science \& Politics, 33, 647-649.

WEALE, A. (2004) Politics as collective choice. In A. LEFTWICH (Ed.), What is politics?: The activity and its study (Cambridge: Polity), 86-99.

WELCH, P. (1996) Teaching skills?, PSA News, Winter.

WHITEMAN, D. (2003) Teaching green: Experimenting with green values in the classroom, PS: Political Science and Politics, 36, 87-91.

WOOD, B. and MORAN, M. (1994) The engine room of instruction: Small group teaching, Politics, 14, 83-90.

YORKE, M. (2004) Employability in higher education: what it is - what it is not, Learning and Employability, Higher Education Academy/ESECT. 